\title{
Linking land use and forestry transition with depopulation in rural Nepal
}

\author{
M. Poudel ${ }^{1 *}$, G. Kafle ${ }^{2}$, K. Khanal ${ }^{3}$, S. Dhungana ${ }^{1}$, B. N. Oli ${ }^{4}$, A. Dhakal ${ }^{5}$ and U. Acharya ${ }^{6}$
}

Migration borne depopulation has been emerging as a new dimension of conservation challenges. Existing body of knowledge, however, lack in-depth understanding of this emerging dynamics of depopulation and its forestry implications. Aiming to analyze implications of migration borne land use transition, this study investigated the nature and impacts of migration in rural communities involved in managing community forestry and other tree resources This study was grounded in the experiences and perceptions of community forest users groups in Parbat and Lamjung districts and applied a pragmatic approach to social science, involving the collection of both qualitative and quantitative data. A total of 218 semi-structured interviews, two focus group discussions and three stakeholders' consultations were conducted. Spatial changes in land use were analyzed using Landsat images of 2000 and 2016 and other existing land use maps. The study found decreasing trend of population growth and identified out-migration of local youth as the main driver. Identified underpinning causes motivating for migration include desire of higher education, employment and resettlement, poverty and poor access to education, markets and other opportunities. This study found negative correlation between migration and farming activities but positive correlation between forest and tree coverage. Forests and other woodland increased but none forest area, most of which were farmlands, decreased. Community forests were getting denser but they lack proper management, abandoned farmlands were turning into bushes, which have increased the risk of forest fire. This study showed very poor understanding of REDD+ and related issues at community level and suggests substantial gaps in policies and procedures to translate migration borne land use transition into opportunities for generating multiple benefits including carbon finance as an additional benefit.

\section{Key words: Community forestry, land use, migration, REDD+}

$\mathrm{D}$ epopulation refers substantial reduction in population (Cambridge Dictionary) and migration is considered the major reason behind ((Wikipedia). Human migration is the movement of people from one place to another with the intentions of settling, permanently in the new location in most cases (Dietz and Rosa, 1994). Migration from rural areas to urban areas has been substantially contributing depopulation in rural areas globally (Okhankhuele and Opafuns, 2013). As reported by Todaro (1997) movement of people from the country sides to cities of Africa, Asia and Latin America has been considered as an unprecedented phenomenon in the history. Such movements are often over long distances and from one country to another. Bremner and Hunter (2014) reported an estimation of 230 million international migrants by 2013 and projected to over 400 million by 2050 . In addition to transcountry (international) migration, internal (within country) migration is also prominent across the globe; indeed, this is the dominant cause of rural depopulation globally (Todaro, 1997).

Analyzing coupled social and ecological systems are crucial for deeper understanding of human migration. Studies have identified several causes and consequences of human migration. Todaro (1997) reported that poverty and insecurity prevailing in rural areas are the primary reasons for migration. He warned huge environmental consequences of human migration across the globe. An investigation by Henry et al. (2004) in Burkina Faso found migration as a coping

'REDD Implementation Center, Babarmahal, Kathmandu, Nepal; *E-mail: mohanprasadpoudel@gmail.com

${ }^{2}$ Freelancer forester

WWF/Hariyo Ban Project,Nepal

${ }^{4}$ Ministry of Forests and Environment

${ }^{5}$ Freelancer RS GIS expert

${ }^{6}$ Freelancer economist 
strategy of poverty and environmental stresses. Warner (2010) argued that migration and displacement are multi-causal issues and interact with environmental factors which affect social and environmental outcomes. Deforestation and forest degradation in many cases are believed to be outcome of human migration. Meeting migration borne demand of fuel wood, timber, agricultural lands and other resources has been considered a major challenge in tackling deforestation and forest degradation and conserving biodiversity and providing environmental services in a sustainable manner particularly in urban and sub urban areas.

Contrary to the above studies (e.g. Basnet, 2013; Chidi, 2015; Henry, 2004; Knight, 2003; Poudel et al., 2014) highlighted a different consequence of depopulation arguing as an emerging dimension of conservation challenge globally. Knight (2003) argued that depopulation leads to changes in local patterns of land uses due to agriculture contraction, increase in fallow lands and wild vegetation with far reaching ecological consequences and food deficit. Migration borne conservation concerns have been dramatically changed in Nepal in the last two decades. In the past, expansion of agriculture land because of rapid population growth was considered one of the main causes of growing environmental degradation in Nepal (Ekholm, 1975) but in the last two decades heavy out- migration of population from rural hill and mountain areas has resulted growing land conversion and abandonment (Chidi, 2015). A study undertaken in Gorkha, Nepal by Poudel et al. (2014) showed that youth migration for employment and education from rural communities has reduced labour force and the implication is that traditionally cultivated lands have been turning either into bare land or unmanaged bush. Basnet (2013) and Gautam (2008) also highlighted this issue as a new conservation challenge in Nepal's rural landscape. Poudel et al. (2014) revealed positive association between depopulation and tree cover and argued that reduced farming activities as a consequence of youths' out-migration from rural Nepal is likely to offer conducive environment for effective REDD + implementation. Despite indicating an existence of correlation, the above mentioned scholars, however, have argued that existing body of knowledge in Nepal lack indepth understanding of this emerging dynamics of depopulation and its forestry implications including REDD + .The main objective of this study was to reflect emerging depopulation borne issues of land use and forestry transition in the landscape of rural Nepal and the specific objectives were:

i) To assess what correlation do exist between depopulation and land use practices in rural Nepal and explain underpinning reasons,

ii) To explain opportunities and challenges of the land use and forestry transition linking REDD + , and

iii) To provide policy inputs for the Government of Nepal in the context of REDD+ readiness.

\section{Materials and methods}

\section{Study sites}

Two criteria used in site selection were (i) study sites under the Hariyo Ban project and (ii) persistence of migration. So the basis of study area selection was that districts under Hariyo Ban project with persistence of migration issues. Study team consulted Hariyo Ban Project staffs and related District Forest Offices (DFOs) and concluded that Parbat and Lamjung districts are areas of high migration among the Hariyo Ban project districts. Two Village Development Committees (VDCs) namely, Arthur in Parbat and Maling in Lamjung were selected as the study sites. DFOs and District Development Committees (DDCs) recommended these sample VDCs based on their official records particularly on migration trend and understanding on other social and environmental contexts driving migration.

\section{Arthur VDC, Parbat district}

The VDC, also known as Arhur Dandakharka, is situated $\left(28.21^{\circ} \mathrm{N} 83.78^{\circ} \mathrm{E}\right)$ in eastern part of Parbat district covering an area of 1,446 ha (Fig. 1). Walking distance from the district head quarter "Kusma" takes about 6 hours and road travel is about 25 kilometer. The area can also be accessed from Pokhara and Syangja. Climate varies from sub-tropical to temperate. The VDC was characterized by a heterogeneous society with mixed castes and ethnicities. Major castes living in the area were Bramin/Chhetri, Indigenous (Janajati) and Dailt comprising 60\%,30\% and $10 \%$, respectively. Population composition of male and female was $55 \%$ and $45 \%$, respectively, 
with average family size of 3.72 . The total population of the VDC was 2,818 in 2011 (CBS, 2011).

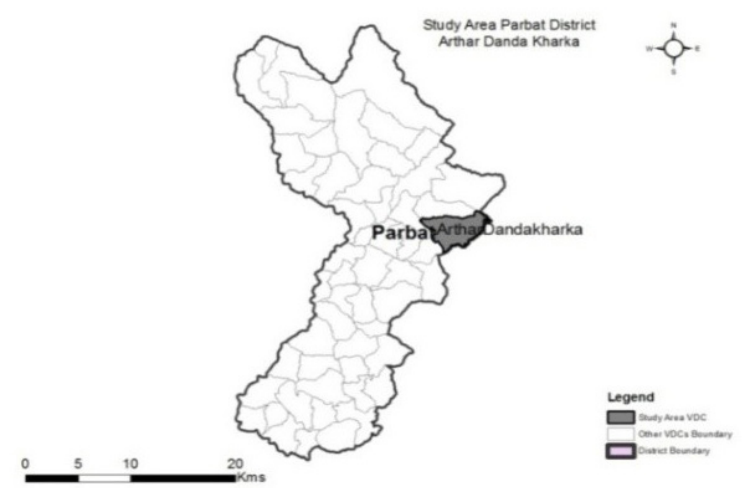

Fig.1: Location of Arthur VDC in Parbat

\section{Maling VDC, Lamjung district}

It is located at western part of Lamjung $\left(28.23^{\circ} \mathrm{N}\right.$ $84.29^{\circ} \mathrm{E}$ ) district covering an area of 2,070 ha in the middle hill region of Nepal (Fig. 2). Climate varies from sub-tropical (Sal forest) to temperate (Quercus- Rhododendron forest). Walking distance from district head quarter, Besi Sahar to Maling is 5 hours and the road travel is about 40 kilometer. Majority of the population belonged to indigenous groups (Gurung and Magar, 74\%), followed by Dalit (24\%) and other (Brahmin/ Chhetri, 2\%). The total population and households of the VDC were 1,224 and 308, respectively. The female population (54\%) was higher than the male (46\%) population (CBS, 2011).

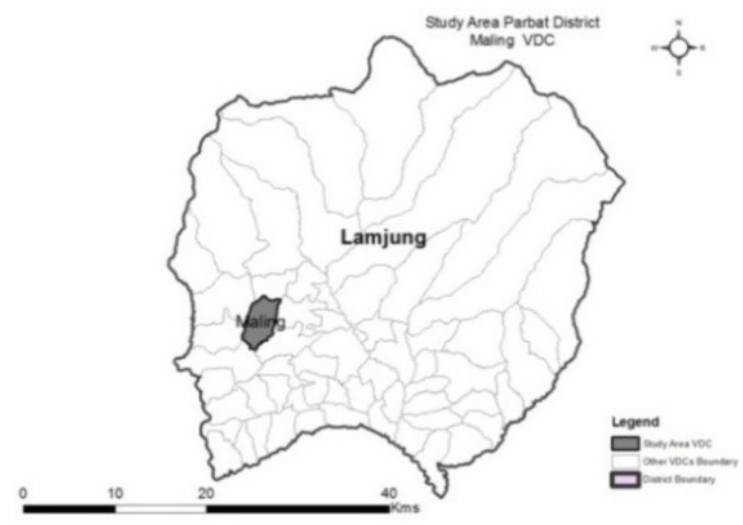

Fig. 2: Location of Maling VDC in Lamjung

\section{Study methods}

\section{Design}

This study primarily applied a cross sectional research design that provides the opportunity for an in-depth examination of many viewpoints in the case study sites, at one point in time (Kumar, 2011;Neuman, 2006). A mixed methods research approach that combines qualitative and quantitative data in a single research design was applied. Mixed research approach can be understood as a synergy of both qualitative and quantitative approaches to obtain the complete picture of the phenomenon investigated (Bickman and Rog, 2009).

\section{Data collection}

The research questions demanded diverse data types including qualitative (perceptions and experiences of local people, civil society, development agencies and government agencies), quantitative (demography, income, land and other property holding, etc) and spatial data (images, maps, location, etc). Meeting such a diverse data requirements, the study applied the following data collection techniques:

- Household survey: A comprehensive semi structured questionnaire was used for the household survey. Total of 218 households (112 from Maling and 106 from Arthur VDCs) were interviewed using experienced local data collectors. Households were selected randomly from VDC record. The research assistant involved and supervised the survey process. Other members of the study team also partly joined the survey. Household survey was conducted between July and September, 2016.

- Community consultation: A community level consultation meeting was held in each site in October, 2016. Community Forest User Group (CFUG) committee members participated in the consultation meetings. Two committee members (a male and a female) from each CFUG that were functional in the study sites took part for one day consultation meeting. In case of Maling where only few CFUGs were functional, additional participants from proposed CFUGs, local women and Dalit representatives were also invited. 
- District level and policy level consultations: A district level stakeholder consultation meeting was organized in each district after completing the survey and community level consultations. Districtlevel government offices dealing with forestry, agriculture, livestock, local development and social welfare; civil society organizations like Federation of Community Forestry Users Nepal (FECOFUN), Nepal Federation of Indigenous Nationalities (NEFIN), Himalayan Grassroots Women's Natural Resource management Association of Nepal (HIMAWANTI), Federation of Nepalese Chambers of Commerce and Industries (FNCCI), and other related agencies in consultation with DFOs were invited for the consultation meetings. The policy level consultation meeting was organized in Kathmandu in November, 2016. This consultation meeting shared preliminary findings of the study and sought feedbacks from the participants.

- Spatial data collection: Landsat images of 2000 and 2016 were assessed for land use trend analysis. Spatial data available in VDC and DDC profiles were used to verify changes in land use and forestry. Google maps/images were also used to verify spatial analysis.

\section{Data analysis}

Data collected using different tools were first organized into a excel sheet so they could be systematically analyzed in detail. This process involved (i) Bringing all recordings and notebook entries together (aggregate) (ii) identifying the main themes, (iii) classifying responses under the main themes (disaggregation).

\section{Qualitative data analysis}

Descriptive information related to each research question were categorized (aggregated) and analyzed to draw findings. The following paragraphs describe the qualitative data analysis process used to address different issues raised by this research.

- Analysis of drivers of migration: Local social and economic contexts that might have motivated local people to migrate from their place of origin were assessed. Perceptions of local people were noted/recorded during survey, consultation meetings and informal talking were primary data sets for the analysis. Migration drivers from each respondent were listed and prioritized based on the frequency (i.e. more the respondents reporting, highest the priority).

- Analysis of forest transition: This analysis drew information on changing activities, values and priorities of forest management (e.g. community, leasehold and private forests) linking with depopulation, particularly focusing on out-migration of youths. Experiences and perceptions expressed by the local communities, relevant districts and national level stakeholders were interpreted in the light of the literature.

- Analysis of opportunities and challenges: Given that one objective of the study was to understand how out-migration might have offered opportunities and challenges for managing forests and related resources. This study explored livelihood strategies / practices being practiced in the case study sites, and assessed how those livelihood practices have been influenced by migration. Identified causes and effects of livelihood practices were interpreted to explore opportunities and challenges emerging for different forest management regimes.

- Analysis of economic potentials of private forestry: This analysis focused on economic prospects of trees grown in private land. Accessibility, timber prices, procedural hurdles and availability of skilled human power were some major variables analyzed to understand economic potentials of tree growing and retaining in private land.

- Analysis of potential linkages with REDD+: Outcomes of all the above analysis were linked with REDD+ policy regimes and interpreted its linkages with depopulation that have been experiencing as a result of youth out-migration from rural communities. Conclusions and policy recommendations were drawn based on identified linkage between REDD + and depopulation in rural landscape in Nepal.

Collected quantitative data were first arranged and tabulated in spreadsheets of Microsoft excel. Spreadsheets were then used to display descriptive statistics, to develop figures, charts and graphs from variables of interest. 
Those figures and graphs were then used to substantiate related qualitative data.

\section{Spatial data (land use trend analysis)}

Landsat images of year 2000 and 2016 covering the case study sites were orthorectified for geometric corrections using rigorous mathematical model (Toutin's Model) with collected ground control points (GCPs) and high resolution digital elevation model (DEM). Geometrically and atmospherically corrected (for haze and cloud) and classified using object based image analysis (OBIA) method. Rule based classification was done on the segmented image objects using spectral and textural properties. Forest and non-forest areas were classified by defining a "containment membership function' for a threshold values for the defined spectral and textural properties of image objects. The GCPs were collected using national topographical datasets like road and river vector features. The DEM was generated using contours and spot levels from the national topographical data. Independent check points (ICPs) were collected for assessing the accuracy levels of the orthorectification process.

\section{Results and discussion}

\section{Land use and forestry transition}

Land use transition was assessed comparing Landsat images of 2000 and 2016 and complementing from recent google maps, ground controlled points and experiences of local people. Overall accuracy of the classification was $93.67 \%$ on comparing the forest/non-forest classes with the visually interpreted points. The user's accuracy was $91.71 \%$ in the forest class only. Similarly, producer's accuracy was $79.70 \%$ for forest class. This is, however an indication of accuracy based on visual interpretation of Google Earth images using human judgment.

Results showed that forest area was increased by $6 \%$ (77 ha) in Arthur VDC and 5\% (75 ha) in Maling VDC between 2000 and 2016. Figures 3 and 4 and table 1 show land use and forestry transition in the studied sites.

Although overall forest area appeared to be increased, there were both way shifts in the land use (Table 1). For example, 82 ha under forest in 2000 in Arthur shifted into non forest in 2016. On the other hand, 158 ha non forest area was converted into forest area. Situation was not very much different in Maling also; 66 ha under forest
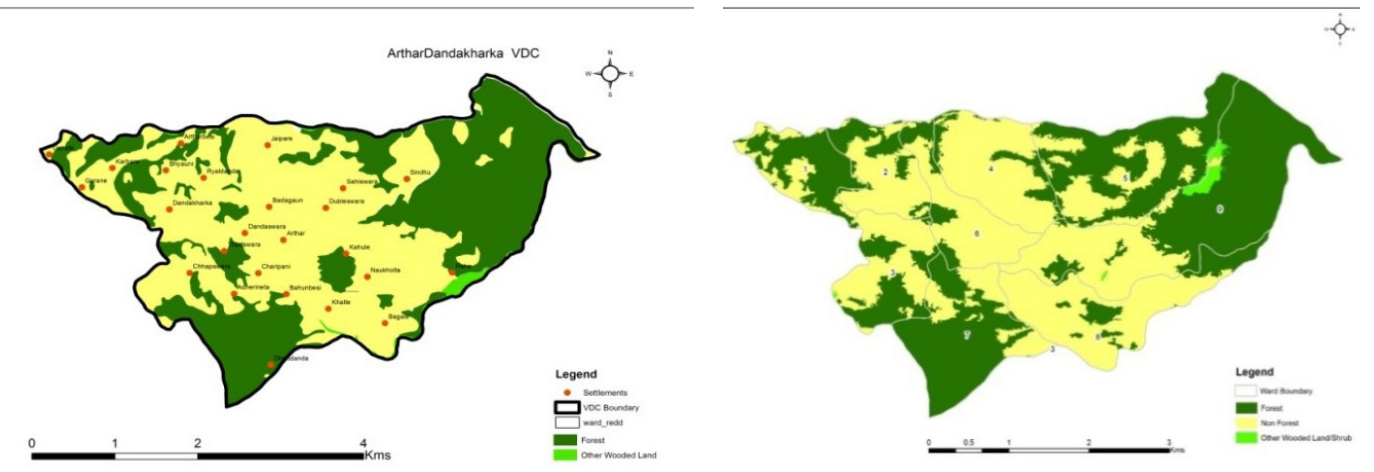

Fig. 3: Showing changes in forests area in Arthur VDC, Prabat district
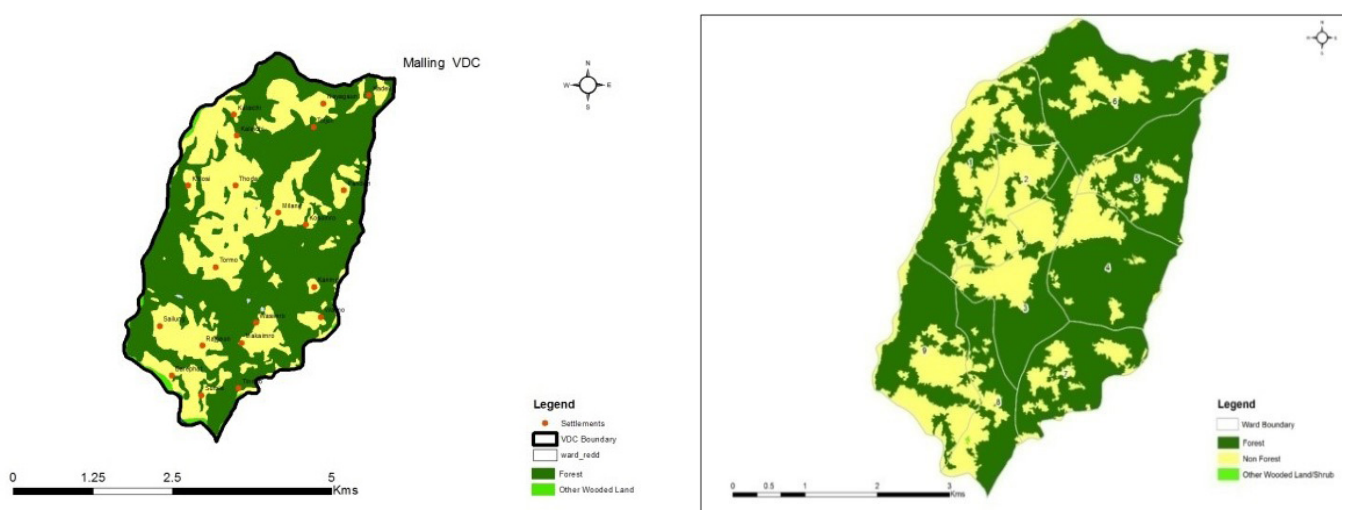

Fig. 4: Showing changes in forests area in MalingVDC (2000-2016) 
Table 1: Wall to wall land use change matrix in the case study sites

\begin{tabular}{lccccc}
\hline & \multicolumn{5}{c}{ Wall to wall change matrix (area in ha): 2000-2016 } \\
\cline { 2 - 6 } & Forest & Non forest & Other woodland & Total 2000 & Site \\
\hline Forest & 507 & 82 & 7 & 596 & Arthur \\
Non forest & 158 & 555 & 10 & 723 & 17 \\
Other woodland & 8 & 2 & 7 & $\mathbf{1 3 3 6}$ & Maling \\
Total 2016 & $\mathbf{6 7 3}$ & $\mathbf{6 3 9}$ & $\mathbf{2 4}$ & 908 & 580 \\
Forest & 840 & 66 & 2 & 6 & \\
Non forest & 139 & 480 & 2 & $\mathbf{1 4 9 5}$ & \\
Other woodland & 4 & 1 & $\mathbf{1 0}$ & & \\
\hline Total 2016 & $\mathbf{9 8 3}$ & $\mathbf{5 0 5}$ & & & \\
\hline
\end{tabular}

in 2000 appeared to be converted into non forest while 139 ha non forest area converted into forest. Other woodland increased from 17 ha to 24 ha in Arthur while changes in other woodland found to be increased by 3 ha in Maling. None forest area decreased by 84 ha and 75 ha in Arthur and in Maling, respectively.

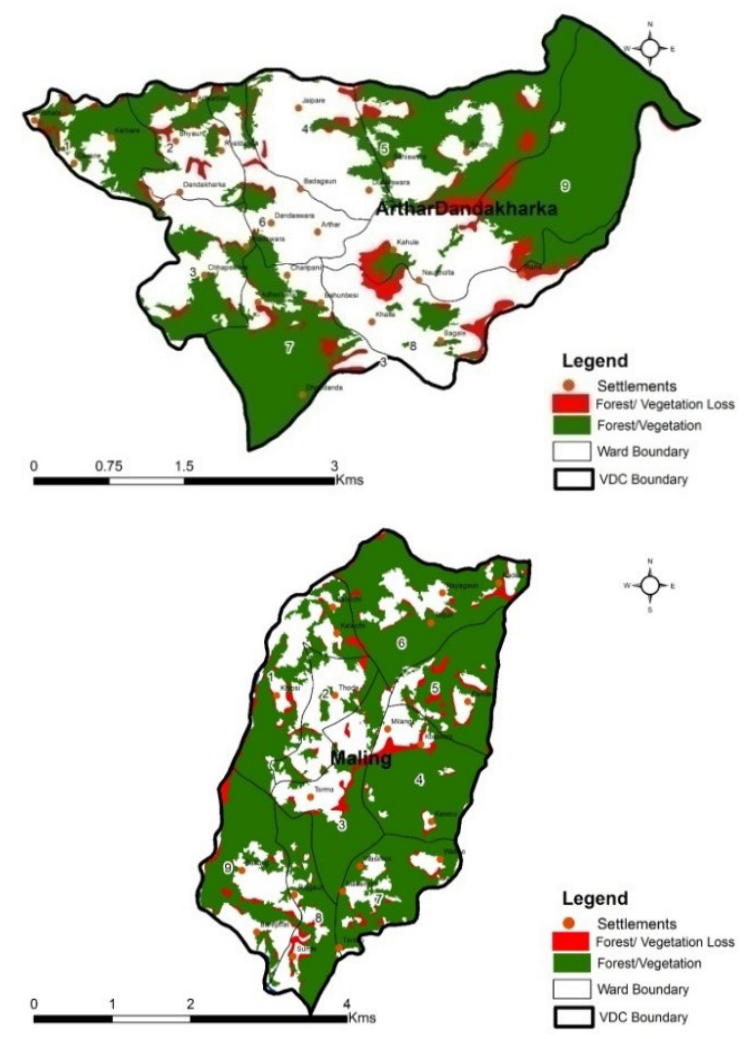

Fig. 5: Illustrating forest loss in case study sites in between 2000 and 2016

Figure 5 illustrates spatial locations of land use changes occurred between the two time points 2000 and 2016. Looking at forest loss areas, they are mostly in linear fashion suggesting road construction was the main reason behind. Spatial alignment of the increased forests and tree cover also, to some extent, appeared to be in linear trend suggesting that marginal land and property boundaries were the first choice for retaining tree in the previously cultivated areas.

Experiences and perception of local people in the case study sites were very much similar to the outcome of the above spatial (images) analysis. Ninety per cent of the survey respondents reported reduced farming activities and increased tree cover in the landscape. Participants of the consultation meetings in both sites confirmed the outcome of the spatial analysis of the land use transition. They reported that tree cover in cultivated lands has been increased more rapidly in recent years and most of the newly developed tree cover is in marginal land and around the land parcel boundaries.

Overall result of the forestry transition analysis is that tree cover has been increased in the study sites. The following section analyses underpinning reasons of the tree cover increasing trend.

Underpinning reasons behind the trend of forestry transition: This study found reducing trend of human population in the both case study sites. It was reduced by $26 \%$ and $34 \%$ between 2000 and 2010 in Arthur and Maling, respectively. Total population of 3,436 in 2000 decreased to 2,618 in Arthur. For the same period, total population of 1,857dropped to 1,224 in Maling. Figure 6 illustrates trend of population changes in both sites. Research participants also reported 


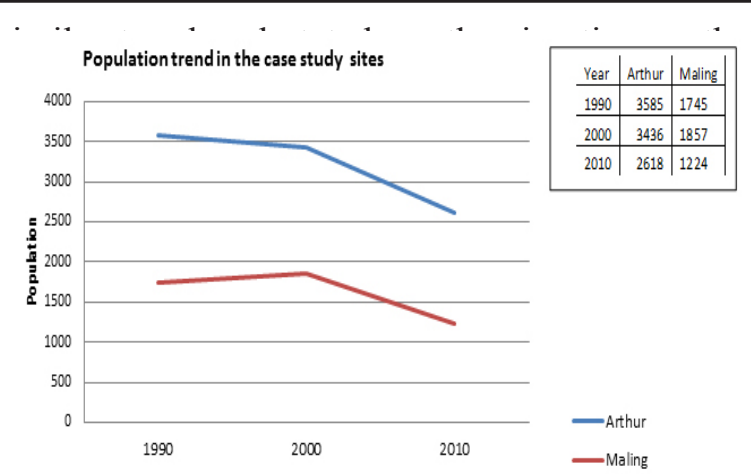

Fig. 6: Showing population trend in the case study sites

Responding a concern related to the causes of depopulation, research participants reported "youths out-migration" as the main causes. They also reported that ongoing trend of out-migration has underpinned the increased tree cover in the study sites. There were two categories of human migration in the study sites, namely permanent and temporary. Permanent migration involved shifting the whole family from their original place to the new destination. This type of migration found to be negligible comparing to the temporary one. Temporary migration involved short term migration with no intention to settle down somewhere else, at least at the time of leaving home at the beginning. Education and job seeking were the main reasons of leaving home by youths. Seventy-seven per cent youths from Maling and 55\% youths from Arthur (i.e. $69 \%$ on an average) were out of their home for temporary employment and most of them were working in Golf countries. Permanent job holders (government job) were 13\% in Maling and 36\% in Arthur (i.e. $69 \%$ on an average).

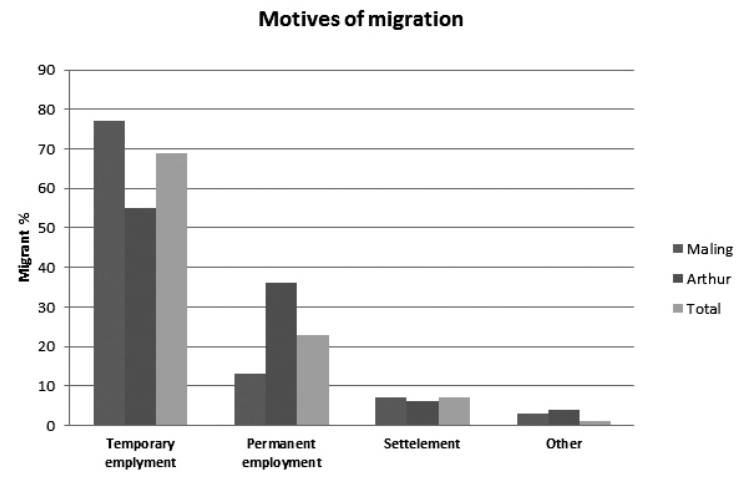

Fig 7: Illustrating reasons of migration from the study sites

Figure 7 illustrates reasons and percentages of temporary migration. This figure does not reflect youth migration for higher education. On an average, one youth from every two households was leaving home to pursue higher education. The desire to seek higher education was found as one of the factors behind the migration of people from the case study sites. However, trend of leaving home for education was found higher in Arthur than that of Maling. Temporary migration for seeking jobs was higher in Maling. Most of the participants in the CFUGs consultation meeting reported that youths have no choice, so they have to leave their home if they would like to pursue further education after high School. Higher secondary level education was started in some cases, although, villagers' first choice was cities for their children's higher education. One participant, who has recently sent his son to Kathmandu for further education in college, said "the school in the village lacks qualified teachers and teaching materials".

In addition, marginal farm productivity and lack of employment in the village had also forced young people to migrate. In response to a question "what underpins villagers to leave their family?" 55\% participants from Arthur and $50 \%$ from Maling reported poverty and $80 \%$ from Arthur and $75 \%$ from Maling reported lack of employment opportunities as the main reason underpinning migration. However, these figures do not incorporate migration for higher education. Participants stated low productivity, difficult access to market, lack of support in income generating activities and lack of family respect as the underpinning reasons motivating youth to migrate.

All of these reasons underpinning migration appeared to be influencing land use practices. Almost all research participants reported that farming activities such as crop growing and capacity of livestock holding have been largely affected by the migration. Research participants described both positive and negative influences of migration on forest condition.

Positively, migration reduced farming activities, hence reduced resources consumption. $63 \%$ of the household respondents $(\mathrm{n}=218)$ believed that the pressure in the forest has been decreased due to reduced number of livestock and firewood demand. According to them, extent of traditional farming has been shrinking each year. An elderly farmer from Arthur VDC, Parbat said, for example: 
"...because of migration, either old (retired) or disabled people are remaining in the village. This has resulted in a decrease in farming activities hence reduced fire and grazing in the forest...".

On the negative side, however, with so many people migrating, villages lack the manpower to deal with emergency situations like forest fire. A village leader, who has been supporting villagers in establishing community forests in Maling VDC.

District level stakeholders such as DFOs, FECOFUN leaders and other line agencies totally agreed with the experiences and perceptions reported by the community forest users.

Local people did not only report an increase in forest but they also reported some losses in existing forest area. Explaining reasons behind the forest loss, consulted CFUG, members from both sites reported two main reasons (i) road construction and (ii) landslides. One participant of age 34 representing Dalit group in Maling said "recent trend of road construction in our village has not only destroyed our forests but also increased land slide and soil erosion". Linear features of the deforested area as shown in the classified maps also justify this argument.

It was also found that most of the trees being retained in the cultivated land were in linear arrangement and overall crown cover was not exceeding $10 \%$. It was noticed during field visit that trees were mostly coming up in unproductive, marginal and sloppy land. Supporting to this, one of the women respondents from Arthur VDC argued that villagers prefer to retain tree in less productive, sloppy and marginal land. She said,

"productive land parcels are still cultivated and I do not think anyone in the village would like to retain trees there soon".

To sum up, profound out-migration in both study sites resulted several social and environmental outcomes. Desire of higher education, poverty, lack of employment opportunities and inaccessibility were some major reasons motivating local people to leave their home. Most of the villagers migrated seeking better income and employment. Migration has both positive and negative influences in land use and forestry transition.

Opportunities of emerging forestry transition: Findings discussed earlier suggest that migration has not only supported forest protection but also resulted into increased tree cover beyond the forest boundary. Land use transition from agriculture to agro-forestry, if not fallow-forestry, has offered several opportunities for managing mountain landscapes in a sustainable manner. Opportunity has also been generated in contributing emissions reduction and climate change mitigation. This section examines emerging opportunities and challenges of improved and increased tree cover in the landscape.

Opportunities for community forestry: Reduced demand of forest products has created opportunities for better and diversified management of community forests. High demand of forest products like fodder, firewood, timber and farming tools to meet subsistence requirements are considered major drivers of deforestation and forest degradation (MFSC, 2010). Consulted participants including local communities, district level stakeholders and policy actors reported that community forests around the villages have been getting better because of reduced grazing and less firewood and fodder collection. Survey data showed that livestock keeping strategy has drastically changed from all time grazing (throughout the year) to stall feeding in most of the households. Data showed that average livestock size (including buffalo, cow, goat and sheep) per household were reduced by $36 \%$ between 2000 and 2016. Average livestock size per household in 2000 and 2016 were 7.5 and 4.5, respectively. Looking separately, livestock holding (i.e. 6.5/ hh) in Maling was significantly higher than in Arthur (i.e. 3/hh). Firewood collection from forest was also reportedly reduced in recent years comparing 15 years back. Local people from both sites reported three important reasons behind: (i) reduced demand (ii) availability of tree resources in farmland and (iii) use of energy efficient stoves and alternative energy. 
Local perception was that grazing, fodder and firewood collection and boundary encroachment for farmland expansion were the major reasons challenging betterprotection of community forests. They believed that migration has provided an opportunity for making community forestry more sustainable and beneficial for local communities rather than just meeting subsistence requirements. They can sale surplus forest products like firewood, timber and NTFPs to the market; they can go for PES such as royalty for drinking water supply; biodiversity and ecotourism. Survey result substantiates the above arguments. Ninety-four per cent respondents believed that migration has positive effects on community forestry (Fig. 8).

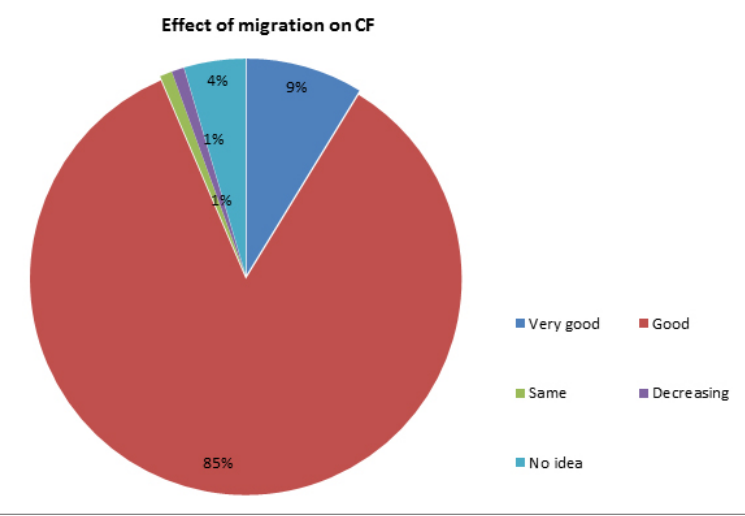

Fig 8: Showing local peoples' perceptions on migration effects to $\mathrm{CF}$

Responding a concern on potential opportunities of migration on community forestry, district level stakeholders from both districts argued that reduced livelihood dependency on forest opens expanded scope like focusing on income generation through sustainable harvesting and marketing of forest products, benefiting from carbon trading project (i.e. REDD+) and other PES projects in the long run. Research participants witnessed increased women leadership in rural communities as a result of young male migration. They argued that absence of young male in communities opens more opportunities for women in decision making.

Opportunities for government managed forests: As in community forestry, migration has directly and indirectly supported forest conservation. DFO officials working in the study sites reported that incidents of illegal activities like timber smuggling, pole cutting, firewood and fodder collection and forest fires have been reduced in recent years. Local participants also agreed with the DFO staffs and added that reduced demand as a result of reduced human and livestock population and limited farming activities automatically reduced pressure in the forest.

Opportunities for private forests: Depopulation mostly because of out-migration of youths opens opportunities for expanding tree cover outside the traditional forests in government land. As discussed earlier, so many previously cultivated land parcels have now been converted into forest . Although all of such land parcels in the landscape do not fall under the forest definition, they can be considered as tree dominated areas. Such a transition opens an opportunity for developing private forestry and exploring economic and ecological potentials. Although, assessing opportunity costs of private forest and comparing economic benefits of farming with private forestry was beyond the scope, this study explored local experiences and perceptions on likely economic implications.

Study participants from both VDCs believed that tree growing in marginal and sloppy areas may be beneficial than that of farming. However, most of them argued that tree growing in productive farmland may not be so unless commercial and multipurpose tree species are planted with easy market access. Fifty per cent respondents believed cultivation is the best economic option in most of the previously cultivated areas (i.e. paddy field and other flat terraces) and 38\%, however, suggested tree plantation as the better economic option in the previously cultivated areas. They argued that effective and regular cultivation needs intensive daily inputs, which is almost unlikely to be happened because of lacking labourers. Rest $12 \%$ respondents could not stand themselves to either sides hence said No Idea (Fig. 9).

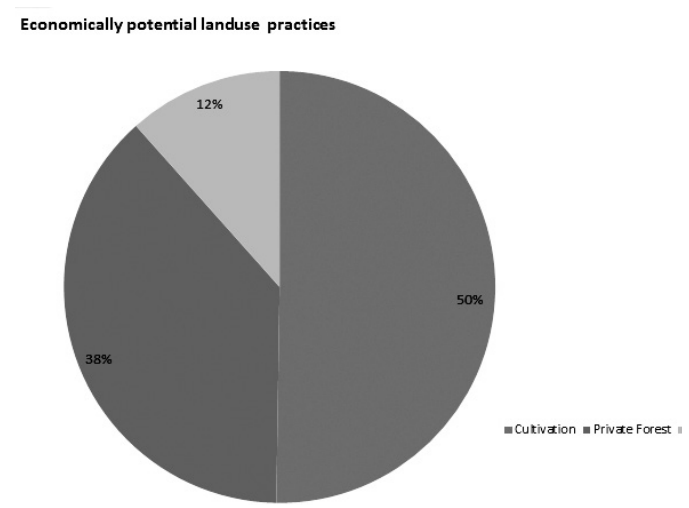

Fig. 9: Showing local peoples' perceptions on economically potential land use practices 
Challenges of emerging land use transition for sustainable forestry: This study found several challenges of migration borne depopulation and land use transition for development and sustainable management of forests and tree resources in the case study sites. The following paragraphs describe identified challenges for different management regimes.

\section{Challenges for community forestry:} Sustainable management of community forests requires active involvement of local communities throughout the process of its development and implementation. Lack of young population in communities appears to be a huge challenge for managing community forests as an approach to deliver multiple benefits including timber, non- timber, medicinal, economic, biodiversity, environmental and social. Study participants argued that denser (high density) community forests have high risk of fire not only in the forest but also in the village. Increasing tree resources in the farmlands are connecting villages to the forests in many cases.

Responding a concern "how do you link migration with forest fire incidents", one of the CFUG, chair persons from Arthur VDC said:

"...if forest fire occurs during the season of migration (winter and early spring) that could be devastating because the village lacks young fire fighters..."

He also reported that seasonal migrants sometime access the forest illegally to get required resources (firewood in particular), because they usually miss the regular (annual) distribution.

Lack of technical understanding on forest management operations like thinning, pruning, and application of fire safety measures has been identified another challenge for effective management of community forests. Seventy per cent of the respondents identified migration as one of the main reasons behind lack of proper management of community forests. They argued that elderly people taking care of CFUGs lack required energy, skill and enthusiasm to plan and implement silvicultural operations in their forests. So they simply impose tight rules and protect forests rather than utilizing sustainably.

Challenges were also identified in capacity building. Despite delivering several capacity building activities like training, communities were lacking skilled human power like harvesting operators, nursery workers and NTFP collectors. Consulted local communities reported that most of the trained youths have migrated and as a result activities could not be implemented effectively and efficiently. Income generating activities also could not be undertaken effectively because there were no young and interested people available in the village.

\section{Challenges for government managed forests:} This research could not find many migration borne challenges for government managed forests. Forest fire was one of the few challenges. As discussed earlier, access to forests for grazing and other activities reduced in recent years mainly because of migration. As a result, mostly understory forest become dense and increase fire hazard. Another challenge reported was the wildlife human conflict. Local people reported that wildlife (e.g. monkeys, leopard and wild pig) population have been increased in the forest, so there are incidents of crop damages and cattle losses. Government agencies will have to find better solution of these challenges.

Challenges for private forests: Despite increased tree coverage in the landscape and associated opportunities as discussed earlier, this research identified several challenges for private forestry. Ninety per cent of the respondents were worried about possible degradation of their land, fire occurrences, wildlife attacks and other crimes hiding behind the bushes. It was observed during field visit that abandoned cultivated lands were partly covered by bushes and bamboos and partly remained fallow. Despite having potentials of growing multiple tree species and income generation, land owner were getting nothing from it.

Inaccessibility and procedural hurdles were also found to be challenging private forest development. Although both VDCs were connected with seasonal road network, substantial areas in the VDCs were still out of road access to export timber to market. Seventy-eight per cent of the respondents appeared reluctant to retain tree in their land. They argued that there is no meaning of retaining trees in the farmland if there is no scope of marketing. It was not only inaccessibility demotivating landholders to retain trees in their land but also procedural hurdles. 
They reported several steps to be followed to get timber harvesting permission from district forest offices. All of the participants including survey respondents and other committee members reported that getting permission and delivering timber to the market is beyond the scope of the villager. Local contractors can only manage to get through and as a result tree grower are forced to sell their trees to the local contractors. Implication is that tree growers lacked bargaining power and forced to sell at the lowest price. Few contractors operating in these sites were also not facing problems mainly because of unavailability of labours and high production cost. One local contractor in Parbat reported that per unit cost in less accessible areas gets higher than the timber available in the market.

Policy gaps in addressing migration borne forestry transition: Importance of private sector in addressing land use, forestry and climatic issues as discussed have been realized in recent years. Recent policy shows that various initiatives to onboard private sector at the policy and institutional level have been undertaken. In the last few years some major policies like the Climate Change Policy (2011), the Land Use Policy (2014), the Rangeland Policy (2012), Forest Encroachment Control Strategy (2012), Biodiversity Strategy and Action Plan (2014), Forest Policy (2015) and Forestry Sector Strategy (2016) have been approved with recognition of private sector in managing environmental services. All of these policies pave important pathways towards sustainable forest management and reducing deforestation and degradation through. However, most of the legal, regulatory and institutional arrangements are not revised in the spirit of these newly promulgated policies. At the same time the transition towards a federal governance system would further delay the process. Full implementation of the policies may be compromised until these regulatory and institutions are reformulated. Based on current practices, this study found a huge policy gap in main streaming private forestry, migration borne forestry transition in particular.

First and foremost gap identified was lack of promotional private forestry policy. As discussed in the challenges section earlier, existing policies and practices of private forestry are not easy to comply with. Private forestry activities are regulated under private forest policy. The policy has regulatory provisions like registration of each and every tree, harvesting procedures to be followed and the requirement of transportation permission. However, local communities and tree growers were found unaware of policy provision. Ninety percent of the survey respondents had no idea about the policy provisions. Participants in the consultation workshops reported that local people know nothing about legal procedures to be followed while harvesting and marketing tree products. Implications are that they cannot fix the price of their tree products. The contractors fix the price and tree growers have no option to agree with that. Consulted district level stakeholders, entrepreneurs, civil society representatives and some policy level officials agreed that existing policy on private forestry regulates but does not promote tree growers. An entrepreneur operating a small saw mill and furniture shop in Besisahar said for example:

" steps to be followed for getting harvesting and transporting permits from district forest offices is discouraging not only for tree growers but also for contractors and entrepreneurs" (a small forestry entrepreneur, Besisahar).

Although the government has recently amended Forest Act, 1993 and added several provisions favouring private forestry, local communities, tree growers and small entrepreneurs found to be unaware about it. This shows a huge gap in information dissemination.

Lack of incentivized policy on planting and retaining trees in private land appeared to be limiting private forest. Research participants argued that unless tree growers are ensured that trees in their farmlands generate additional benefits, they will not be motivated to retain trees in it. So far there is no such an incentivizing policy in Nepal. Farmers with limited land have to sustain from regular farm income but tree planting does not generate immediate income. On an average, one should wait more than 20 years to get income from trees. This has been demotivating villagers to plant trees in their land. Instead they prefer to keep it fallow, so they can start farming again. Many participants reported that if the farmland is converted into bush or forests, then it will be difficult for them to cultivate there again. They will have to put more efforts to cut the trees/bushes, remove roots from the soil and make terraces for cropping again and all of 
these increase production cost. Unless trees are insured, incentives (considering alternative land use income) are provided and access to market is eased, establishing forests in private land in the case study is unlikely. Increased tree cover as shown in the image analysis may no longer remain unless policies to incentivize tree grower are put in place.

Policy level experts and forestry officials also agreed that, to some extent, the existing forests and environmental policies have undermined possible scale of farm forestry and its' multiple scopes. In particular, gaps are reported in identifying private and farm forestry potentials in addressing climatic issues, promoting ecotourism, biodiversity and REDD + policy. Available research findings and policy documents are mostly focusing on government forests in dealing with the said issues. Potentials of tree resources outside forests are not properly explored and reflected in the policy documents.

\section{Conclusion}

This study assessed migration borne forestry transition in Arthur VDC, Parbat district and Maling VDC, Lamjung district and explained emerging outcomes, opportunities and challenges linking REDD + policy mechanism. Based on the findings discussed earlier, the following conclusions are drawn.

Research concludes that traditional farm focused land use practices have been changing towards tree dominated farm forestry systems in the rural landscape of Nepal. Forests and tree cover is found to be increased. Land use change was even pronounced in private lands where substantial areas under cultivation in 2000 were either converted into fallow land or partially covered by perennial plants, trees and bamboos in particular.

Research confirms decreasing trend of rural population and concluded that migration is the only reason causing population shrinking. Drivers motivating local youths to leave their home included (i) desire of higher education and (ii) seeking employment. Only few were leaving their original area for resettlement, mostly in big cities and productive Terai areas. Out of the total migrants, $20 \%$ to $30 \%$ migrants ever come back to the village.
Identified implications of depopulation include (i) farming activities were reduced in the area, (ii) productivity of the land degraded, (iii) development activities were affected due to lack of vibrant local leadership, (iv) social security could not be maintained, (v) forests could not be managed and utilized of its potentials, and (vi) local capacity in managing natural resources could not be built on.

Opportunities emerging from migration borne forestry transitions for community forestry are: (i) reduced products demand (ii) enhanced forest condition $(94 \%$ research participants confirmed enhanced CF condition) (iii) enhanced availability of NTFPs and biodiversity, and (iv) controlled illegal harvesting and encroachment for farm land expansion. Opportunities for private forestry are (i) better use of marginal and sloppy areas, (ii) production of multiple products including crops, forages, timber, firewood and fodder, (iii) establishment of forest based small enterprises, (iv) Soil and water conservation, and (v) climate change adaptation. Migration borne forestry transition also appears to be supporting environmental services like water, biodiversity, ecotourism and REDD+.

Challenges for participatory management of forest resources include: (i) lack of vibrant leadership, (ii) degradation of management practices (planting, harvesting etc), (iii) increased fire risk, and (iv) human wildlife conflicts.

Lack of promotional private forest policy was the key policy gap. Existing private forest policy appears regulating rather than promoting land owner to grow trees. Provisions of incentives for tree growing in private land and required insurance for any losses like insect, pests, fire, market failure, etc. were lacking. Policy hurdles were also realized in harvesting, transporting and marketing forest products from private lands. Despite recent amendments in policies that acknowledge importance of private forestry in supporting sustainability of forests and delivering better environmental services, regulating laws, bylaws, procedural guidelines and mind set of executing agencies at local level remained unchanged.

This research found migration borne forestry transition (i.e. increased forest area/ tree coverage and enhanced forest condition) offering conducive 
environment for reducing emissions and enhancing carbon sequestration. However, a lot yet to be done in developing local understanding, revising rules, regulations and service delivery approaches and providing necessary tools, skills and incentives, so tree growers and managers remain motivated in managing tree crops in their lands.

\section{Recommendations}

Based on the findings and the conclusions, this study provides the following recommendations:

\section{Recommendations for land holding migrants}

- Do not leave your land unattended and fallow. In case of not being able to continue farming, plant multipurpose trees and perennial medicinal and aromatic herbs.

- Explore what benefits could be generated from the selected species and develop marketing networks.

- Consult related experts (technicians) available in government offices (DFO, District Soil Conservation office-DSCO, District Agriculture Development OfficeDADO, District Livestock Development Office-DLDO, etc.), civil society organizations and NGOs and get their supports.

- Insure your tree/herb crops as far as possible

2. Recommendations for community forest users groups

- Capacitate women and elders so they can provide effective leadership in managing community forestry (both users and forest).

- Undertake cleaning, pruning, thinning and harvesting operations as planned in the operation plan. CFUGs can contract out these operations to local entrepreneurs. This will not only reduce fire hazard in the forest but also generate income by selling the products. However, a regular and close monitoring is must to make sure that contractors do not violate rules.

- Seek regular support from local forestry authority.
3. Recommendations for local government officials

- Implement capacity building activities targeting women and elders regularly.

- Provide incentives for planting trees in public and private lands. Introduce incentive packages and insurance policies.

- Provide all required technical inputs in developing, managing, harvesting and trading forest products from community managed and privately owned forests.

- Provide fire fighting tools, techniques and incentives. Develop fire lines and undertake regular monitoring. Development of fire fighting teams and networking them could be a smart way to keep local people connected, vigilant and alert.

- Make sure that children are getting better education in the local schools, so parents are not forced to migrate to city center seeking better education for their children.

- Make sure that basic services like agriculture, livestock husbandry, health, market, transportation, legal, administrative, etc. are easily accessible to the villagers.

- Encourage youths to engage in developing local resources based enterprises and income generating activities.

4. Recommendation for policy level stakeholders

- Identify drivers of migration and their underlying causes at different social and environmental contexts and consolidate at national scale.

- Develop an in-depth understanding on migration borne social and environmental implications.

- Identify policy gaps in translating migration borne land use transition into sustainable landscape management opportunities.

- Identify opportunities and challenges for translating migration borne forestry transition into sustainable forestry and effective REDD+ policy intervention.

- Develop necessary policies and mechanisms addressing identified gaps and challenges. 
- Continue consultation and outreaching activities targeting tree growers and community forest users groups.

\section{References}

Basnet, B. S. 2013. Taking migration seriously. What are the implications for gender and community forestry? CIFOR Info Brief 65 Bogor, Indonesia.

Bickman, L. and Rog, D. J. (eds.). 2009. Applied social research methods (2nd edition). California, USA.

Bremner, J. and Hunter, L. M. 2014. Migration and the Environment. Population Bulletin 69 (1).

Chidi, C. L. 2015. Impact of out migration on land use change in Aroundi Khola watershed of Syangja, Western Hill of Nepal. In Environmental Crisis (ed.) Mehta, R. B.. Institute of Social Development and Research, Ranchi, India.

Dietz, T. and Rosa, E. 1994. Rethinking the environmental impacts of population, affluence and technology. Human Ecology Review 1 (2): 277-300. Retrieved from http:// www.jstor.org/stable/24706840.

Ekholm, E. 1975. The deteroriation of mountain environments. Science 189: 764-770.

Gautam, T. R. 2008. Migration and the problem of old age people in Nepal. Dhaulagiri. Journal of Sociology and Anthropology 2:145-162.

GoN. 1993. Forest Act (with amendment in 2016). Ministry of Forests and Soil Conservation, Government of Nepal (GoN), Kathmandu, Nepal.
Henry, S., Schoumaker, B., and Beauchemin, C. 2004. The impact of rainfall on the first out-migration: A multi-level event history analysis in Burkina Faso. Population and Environment 25 (5): 423-460.

Kumar, R. 2011. Research Methodology: a Step-by-Step Guide for Beginners. (3rd ed.). SAGE Publication, London, UK.

MFSC. 2010. Nepal's Readiness Preparation Proposal: REDD 2010-2013. Ministry of Forests and Soil Conservation (MFSC), Kathmandu, Nepal.

Neuman, W. L. 2006. Social Research Methods: Qualitative and Qualitative Approaches. 6th ed.. Pearson Education, UK

Knight, J. 2003. Waiting for Wolves in Japan: An Anthropological Study of PeopleWildlife Relations. Oxford University Press, Oxford, UK.

Okhankhuele, O. T. and Opafunso, OZ. 2013. Causes and consequences of rural-urban migration Nigeria: A case study of Ogun Waterside local Government area of Ogun State, Nigeria. British Journal of Arts and Social Sciences 16 (1): 197-206.

Poudel, M., Thwaites, R., Race, D. and Dahal, G. R. 2015. Assessing Outcomes of REDD+ through Community Forestry in Nepal. Unpublished PhD Thesis, Charles Sturt University (CSU) SAGE publication. Australia.

Todaro, M. P. 1994. Economic Development. 5th ed., New York, London: Longman. UK.

Warner, K. 2010. Global environmental change and migration: Governance challenges. Global Environ. Change, doi:10.1016/j. gloenvcha.2009.12.001. 